\title{
IMPLEMENTATION OF PHET LEARNING MEDIA IN EFFORTS TO IMPROVE ACTIVITIES AND PHYSICS LEARNING OUTCOMES OF STUDENTS IN CLASS XI SMA 4 PEKANBARU
}

\author{
Nefrita ${ }^{*}$ \\ SMA Negeri 4 Pekanbaru \\ e-mail: nefrita@gmail.com
}

\begin{abstract}
The implementation of learning, especially Physics, is currently based on the results of observations still experiencing several obstacles. The tendency of passive students and learning outcomes as part of students still shows results that have not been maximal. Based on this fact, this classroom action research was carried out to improve the learning process and physics learning outcomes of students in the fluid material in class XI IPA $A_{1}$ SMA 4 Pekanbaru, using PHET (Physics Education Technology) media. The type of research conducted is classroom action research consisting of 2 cycles, with the subject are students of class XI SMA Negeri 4 Pekanbaru. Time for the implementation of odd semester 2018/2019 academic year. Data collection techniques used observation sheet instruments for learning activities and fluid material test sheets for physics learning outcomes. Data is analyzed descriptively in percentage representation. The results of the research showed that the learning activities of students had increased from cycle I to cycle II. Furthermore, for physics learning outcomes, students increase from the first cycle to cycle II, with the average results obtained by the good category. Therefore, the application of PHET-based information technology simulation media in physics learning can improve learning activeness and learning outcomes of class XI students of SMA 4 Pekanbaru.
\end{abstract}

Keywords: Static fluid, activity, learning outcomes, PHET

\section{PENERAPAN MEDIA PEMBELAJARAN PHET DALAM UPAYA MENINGKATKAN AKTIVITAS DAN HASIL BELAJAR FISIKA PESERTA DIDIK KELAS XI SMA 4 PEKANBARU}

\author{
Nefrita*) \\ SMA Negeri 4 Pekanbaru \\ e-mail: nefrita@gmail.com
}

\begin{abstract}
Abstrak
Pelaksanaan pembelajaran khususnya Fisika, saat ini berdasarkan hasil observasi masih mengalami beberapa kendala. Kecenderungan peserta didik pasif dan hasil belajar sebahagian peserta didik masih menunjukkan hasil yang belum maksimal. Berdasarkan kenyataan tersebut, maka dilakukan penelitian tindakan kelas ini untuk memperbaiki proses pembelajaran dan hasil belajar fisika peserta didik pada materi Fluida di kelas XI $I P A_{1}$ SMA Negeri 4 Pekanbaru, menggunakan media PHET (Physics Education Technology). Jenis Penelitian yang dilakukan adalah penelitian tindakan kelas yang terdiri dari 2 siklus, dengan subjek peserta didik kelas XI SMA Negeri 4 Pekanbaru. Waktu pelaksanaan tindakan semester ganjil tahun ajaran 2018/2019. Teknik pengumpulan data menggunakan instrumen lembar observasi untuk aktivitas belajar dan

${ }^{*}$ Komunikasi Penulis
\end{abstract}


lembar tes materi fluida untuk hasil belajar fisika. Data dianalisis secara deskriptip dalam representasi persentase. Hasil penelitian diperoleh aktivitas belajar peserta didik mengalami peningkatan dari siklus I ke siklus II. Selanjutnya untuk hasil belajar fisika peserta didik meningkat dari siklus I ke Siklus II, dengan hasil rata-rata 85 katagori sangat baik. Oleh karena itu, penerapan media simulasi berbasis teknologi informasi PHET dalam pembelajaran fisika dapat memperbaiki keaktifan belajar dan hasil belajar peserta didik kelas XI SMA Negeri 4 Pekanbaru.

Kata kunci: Fluida Statik, keaktifan, hasil belajar, PHET

\section{Pendahuluan}

Upaya dalam rangka meningkatkan kualitas sumber daya manusia (SDM), bangsa Indonesia telah melaksanakan berbagai upaya untuk meningkatkan kualitas proses dan hasil belajar dalam setiap jenjang pendidikan agar diperoleh SDM yang berkualitas dan siap bersaing di dunia global. Adapun faktor utama yang saling berkaitan guna meningkatkan kualitas disektor pendidikan, yakni kurikulum, guru dan pengajaran atau proses belajar dan mengajar (Sudjana, 2009).

Sejauh ini pemerintah telah mengembangkan kurikulum 2013 yang diterapkan di Indonesia. mulai tahun ajaran 2013/2014. Penerapannya dilakukan secara bertahap di beberapa sekolah yang dianggap menenuhi untuk menggunakan kurikulum 2013 tersebut. Melalui Permendikbud nomor 69 tahun 2013, kurikulum 2013 dikembangkan dengan memperhatikan faktor tantangan internal dan tantangan eksternal. Tantangan internal diantaranya kondisi pendidikan yang berkaitan dengan tuntutan pendidikan yang mengacu pada Standar Nasional Pendidikan, yang mengupayakan agar SDM memiliki kompetensi dan keterampilan melalui pendidikan. Selanjutnya tantangan eksternal diantaranya terkait dengan pesatnya perkembangan arus globalisasi, serta kemajuan teknologi dan informasi. Berdasarkan kedua tantangan tersebut maka kurikulum 2013 dikembangkan dengan pola pikir pembelajaran berbasis alat multimedia, pembelajaran aktif dan kritis.

Berdasarkan observasi pada saat proses pembelajaran di SMA Negeri 4 Pekanbaru tahun ajaran 2018/2019, dalam pembelajaran fisika di kelas XI IPA 1 diperoleh peserta didik fakta cenderung pasif dan pembelajaran masih didominasi oleh guru, sehingga berpengaruh pada hasil belajar peserta didik yang belum maksimal. Selanjutnya dari data hasil belajar peserta didik tahun sebelumnya pada materi fluida statik menunjukkan nilai rata-rata peserta didik pada umumnya masih rendah yaitu nilai terendah 60 dan nilai tertinggi 70 dengan nilai rata-rata 65 . Adapun penyebabnya karena dalam pembelajaran fisika peserta didik kurang terlibat aktif secara langsung dalam proses pembelajaran, sumber belajar yang digunakan masih terpaku pada buku teks saja sehingga peserta didik kurang aktif dalam proses pembelajaran fisika.

Sesuai dengan Permendikbud nomor 65 tahun 2013 tentang standar proses pendidikan dasar dan menengah yang menyebutkan bahwas dalam standar proses pendidikan dasar dan menengah dapat memanfaatkan teknologi informasi dan komunikasi untuk meningkatkan efisiensi dan efektivitas pembelajaran (Permendikbud, 2013). Pembelajaran menerapkan nilai-nilai dengan memberi keteladanan, membangun kemauan dan mengembangkan kreativitas peserta didik dalam proses pembelajaran.

Seiring dengan berkembang pesatnya sistem teknologi informasi, di bidang pendidikan juga senantiasa bergerak maju menyesuaikan perkembangan tersebut. Dalam hal ini khususnya untuk mendukung terciptanya media, metode dan materi pendidikan yang turut serta memajukan perkembangan sektor pendidikan. Oleh karena itu, dalam dunia pendidikan juga harus mampu memanfaatkan teknologi informasi untuk mengembangkan sistem pendidikan sehingga diharapkan dapat menciptakan interaksi yang interaktif saat proses pem-belajaran berlangsung, yang mana dalam hal ini proses pembelajaran sangat mempengaruhi peserta didik untuk mencapai tujuan pembelajaran.

Upaya dalam rangka meningkatkan proses pembelajaran fisika yang efektif dan efisien, peserta didik perlu dibekali dengan pengetahuan dan pengalaman langsung berdasarkan peristiwa yang dialami di sekitarnya. Gunawan \& Liliasari (2012) 
menyatakan bahwa salah satu alternatif untuk meningkatkan proses pembelajaran fisika yaitu melibatkan konsep fisika yang abstrak dengan cara memanfaatan teknologi informasi yang relevan seperti penggunaan media multimedia interaktif yang terdiri dari teks, hiperteks, suara, gambar, animasi, video dan grafik. Pembelajaran fisika dengan media berbantu komputer menunjukkan adanya korelasi yang positif antara media komputer yang digunakan dengan penguasaan konsep dan keterampilan berpikir peserta didik, serta membantu peserta didik yang mengalami kesulitan belajar.

Salah satu bentuk perkembangan teknologi informasi dalam dunia pendidikan adalah penggunaan media pembelajaran berbasis teknologi informasi yang dapat diterima dengan mudah melalui media berbantu komputer. Media pembelajaran ini dapat berbentuk media simulasi yang nantinya dapat membantu peserta didik untuk memahami ketidakjelasan dan kerumitan materi yang dipelajari. Selain itu, media pembelajaran simulasi ini juga dapat membantu guru menyampaikan hal-hal yang belum tersampaikan saat pembelajaran di kelas. Media simulasi berbasis teknologi informasi ini dimaksudkan juga untuk menarik perhatian peserta didik saat proses pembelajaran fisika berlangsung. Kozma (1991) menyebutkan bahwa penggunaan media simulasi dapat membantu peserta didik dalam mengkonstruksi antara simbol dan grafik yang mewakili fenomena nyata disekitar mereka. Melalui media simulasi diharapkan dapat melatih kemampuan berpikir peserta didik untuk mencapai hasil belajar yang terarah sesuai dengan tujuan pembelajaran.

Keaktifan belajar peserta didik dapat dipengaruhi oleh kemampuan peserta didik dalam berpikir kritis dan kreatif. Kemampuan berpikir kritis dan kreatif peserta didik dapat terbentuk melalui proses mengamati, menanya, ekperimen, mengasosiasi dan komunikasi. Melalui kelima proses tersebut, kemampuan berpikir kritis dan kreatif diperlukan peserta didik dalam pemecahan suatu masalah. Berdasarkan penelitian tentang Teaching Critical and Problem Solving Skills, Snyder (2008) menyebutkan bahwa berpikir kritis merupakan suatu keterampilan yang dipelajari dan harus dikembangkan serta dipraktekkan dan diintegrasikan ke dalam kurikulum untuk melibatkan para peserta didik dalam pembelajaran aktif. Jadi, kemampuan berpikir peserta didik dalam proses pembelajaran turut serta berperan menentukan kondisi keaktifan belajar peserta didik. Gunawan dan Liliasari (2012) menyatakan bahwa kemampuan yang dilibatkan dalam proses menentukan keputusan secara rasional yang akan dimunculkan dalam suatu bentuk peragaan ataupun tindakan adalah kemampuan peserta didik dalam berpikir kritis. Melalui kemampuan berpikir kritis ini dapat memberikan rekomendasi yang baik untuk melakukan suatu tindakan.

Fisika sebagai ilmu pengetahuan yang mempelajari tentang gejala yang terjadi di alam serta interaksinya dengan benda-benda yang ada di sekitarnya, maka untuk mengetahui besarnya nilai yang terdapat pada peristiwa alam yang terjadi tidak jarang fisika banyak dituliskan dalam bentuk matematis. Hal ini terkadang menjadi kerumitan tersendiri bagi peserta didik untuk memahami konsep fisika yang sebenarnya. Melalui media simulasi, hal-hal yang dianggap rumit untuk dimengerti oleh peserta didik dapat disampaikan melalui media simulasi, sehingga peserta didik dapat terbantu untuk memahami konsep-konsep fisika. Selain itu, melalui media pembelajaran dalam bentuk media simulasi diharapkan dapat meningkatkan motivasi belajar peserta didik sehingga proses pembelajaran fisika menjadi lebih menarik dan peserta didik menjadi lebih aktif. memanfaatkan media PHET dalam membantu pelaksanaan tugas pokoknya. Materi pembelajaran dapat dibuat lebih menarik sehingga peserta didik akan lebih termotivasi dalam belajar. Selain itu, peserta didik dan guru mudah mendapatkan pengkayaan materi ajar sehingga akan meningkatkan pemahaman dan penguasaan materi tersebut. Media pembelajaran menggunakan program PHET dapat dijadikan sebagai media yang baik untuk pendidikan khususnya pada materi fisika (Sinulingga, et al., 2016). Penerapan media simulasi PHET dalam pembelajaran fisika Kurikulum 2013 secara konsisten dapat meningkatkan hasil belajar peserta didik (Usiana \& Budiningarti, 2016). Sebagaimana yang disebutkan dalam hasil penelitian Muller (2008) tentang Designing Effective Multimedia for Physics Education, bahwa media pembelajaran berpengaruh dalam pem-belajaran fisika tentang mata kuliah mekanika quantum sehingga peserta didik menjadi lebih tertarik. 
Selain itu peserta didik juga menjadi lebih aktif dalam proses diskusi yang ditunjukkan dengan intensitas peserta didik dalam bertanya maupun menanggapi rekan-rekannya. Peserta didik menjadi lebih percaya diri dalam menyampaikan konsep yang diterimanya melalui penggunaan multimedia.

Guru sebagai faktor utama dalam rangka mencetak SDM yang berkualitas harus mampu menciptakan suasana belajar mengajar di sekolah dengan sebaik-baiknya. Guru harus bisa mengarahkan peserta didik untuk dapat berpikir kritis dan kreatif saat pembelajaran fisika berlangsung, khususnya bagi pengampu peserta didik di kelas sosial yang memperoleh mata pelajaran fisika sebagai mata pelajaran wajib. Sebagai mahapeserta didik calon guru hendaknya harus mempersiapkan diri dengan berbagai keterampilan intelektual yang memadai. Keterampilan tersebut diantaranya meliputi penguasaan konsep dari materi yang akan disampaikan kepada peserta didik dan juga mampu menyiapkan diri dalam setiap perkembangan yang ada dalam masyarakat. Pembelajaran fisika yang berlangsung tidak sekedar menyampaikan materi dengan memberikan ceramah karena fisika merupakan ilmu yang lebih banyak memerlukan pemahaman daripada hafalan. Pembelajaran fisika sesuai dengan penerapan kurikulum 2013 yaitu peserta didik dapat mengusai berbagai pemecahan masalah, konsep dan prinsip fisika untuk mengembangkan pengetahuan, keterampilan dan sikap percaya diri, diharapkan kelak dapat diterapkan dalam kehidupan sehari-hari ataupun sebagai bekal untuk melanjutkan ke jenjang pendidikan yang lebih tinggi.

Berdasarkan latar belakang yang telah diungkapkan, maka judul kajian ini yaitu "Meningkatkan Keaktivan dan Hasil Belajar Peserta Didik Kelas XI IPA 1 SMA Negeri 4 Pekanbaru Melalui Pemanfaatan Media Pembelajaran Berbasis Teknologi". Tujuan penelitian yaitu dengan adanya penggunaan media simulasi berbasis teknologi informasi dalam pembelajaran fisika dapat meningkatkan pemahaman konsep pada peserta didik.

Tujuan dari penelitian ini adalah untuk menerapkan penggunaan media media pembelajaran fisika PHET dalam upaya meningkatkan aktivitas dan hasil belajar peserta didik di kelas lintas minat fisika.

\section{Bahan dan Metode}

Penelitian ini merupakan penelitian tindakan kelas yang menggunakan data pengamatan langsung terhadap proses pembelajaran di kelas dan dari data hasil belajar peserta didik. Langkah-langkah kegiatan yang ditempuh pada pelaksanaan penelitian tindakan kelas ini memenuhi Gambar 1.

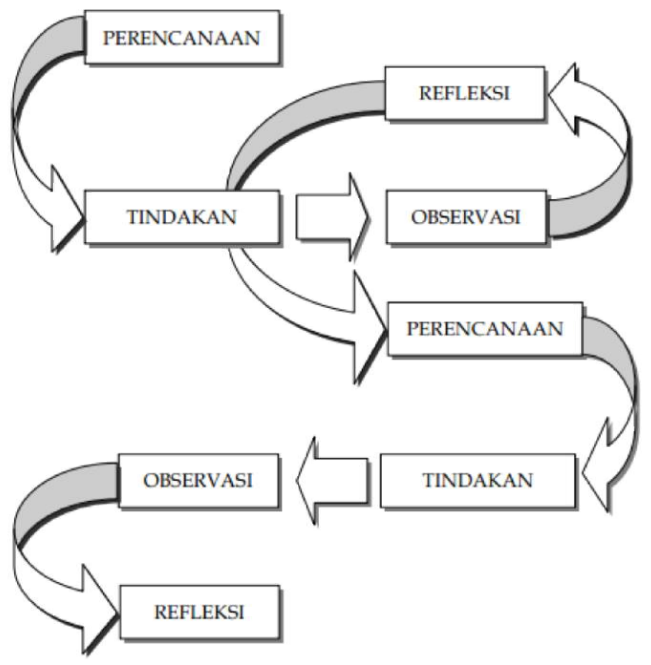

Gambar 1. Siklus PTK model Tagart dan Kemis (Arikunto, 2006).

Prosedur dalam penelitian ini dilaksanakan melalui siklus kegiatan yang terdiri dari dua siklus sebagaimana Gambar 2 . Setiap siklus terdiri atas empat tahap yaitu: 1 ) perencanaan, 2) tindakan, 3) observasi, dan 4) refleksi.

Tahap perencanaan dilaksanakan yaitu: mulai dari observasi awal untuk mengidentifikasi masalah yang dihadapi peserta didik, menyusun skenario pem-belajaran, menyusun tes hasil belajar, menyusun lembar observasi aktifitas peserta didik, dan menyedia kan media pembelajaran PHET terkait materi fluida statik.

Tahap tindakan dilaksanakan dengan melaksanakan pembelajaran di kelas sesuai dengan kegiatan pembelajaran yang telah disusun dan menggunakan media Phet. Kegiatan pembelajaran yaitu: a) Kegiatan Pendahuluan; mempersiapkan peserta didik belajar melalui penggunaan media Phet, memberi motivasi dan apersepsi terkait materi, dan menjelaskan tujuan pembelaajaran dan cara penggunaan media PHET. b) Kegiatan 
Inti merupakan kegiatan utama dalam proses pelaksanaan pembelajaran, membagi peserta didik menjadi beberapa kelompok kecil untuk melaksanakan pembelajaran fisika menggunakan media pembelajaran PHET, memberikan penugasan kepada peserta didik menggunakan media pembelajaran PHET, serta melakukan diskusi untuk merumuskan hasil pembelajaran menggunakan media PHET c) Kegiatan Penutup dimana peserta didik dan pendidik menyimpulkan pembelajaran, melakukan refleksi; dan memberikan tindak lanjut dan umpan balik berdarasakan pembelajaran yang telah dilakukan.

Tahap observasi dilaksanakan bersamaan saat pelaksanaan pembelajaran menggunakan media Phet diberikan. Pada tahap ini dilakukan pengamatan dan mencatat aktivitas peserta didik selama pelaksanaan tindakan penelitian berlangsung. Dalam melakukan obsertvasi peneliti didampingi oleh guru mata pelajaran fisika lainnya.

Tahap refleksi dilaksanakan untuk mengetahui dan menganalisis pembelajaran siklus I yang sudah diterapkan terkait dengan proses pembelajaran yang dilakukan seperti aktivitas peserta didik dan hasil belajar peserta didik pada siklus 1. Hasil refleksi digunakan untuk perbaikan tindakan siklus selanjutnya yaitu siklus II, sehingga diperoleh hasil yang laebih baik dari siklus sebelumnya (Siklus I).

Penelitian tindakan kelas ini dilaksanakan di kelas XI IPA 1 SMA Negeri 4 Pekanbaru. Penelitian dilaksanakan selama tiga bulan, yaitu pada bulan Agustus sampai bulan Oktober semester ganjil tahun pelajaran 2018-2019. Adapun subjek penelitian adalah peserta didik kelas XI IPA 1 SMA Negeri 4 Pekanbaru yang berjumlah 36 orang dengan kemampuan heterogen. Data dianalisis menggunakan pesamaan (1) dan Tabel 1.

$$
\mathrm{N}=\frac{\text { skor } y \text { ang didapat }}{\text { skor maksimum }} \mathrm{X} 100
$$

Tabel 1 Kategori Keaktifan dan Hasil Belajar Peserta Didik

\begin{tabular}{cc}
\hline Interval \% & Kategori \\
\hline $85-100$ & Sangat Baik \\
$70-84$ & Baik \\
$50-69$ & Cukup Baik \\
$0-49$ & Kurang Baik \\
\hline
\end{tabular}

Sumber: Depdiknas, 2006.

\section{Hasil dan Pembahasan}

Penelitian tindakan kelas yang dilaksanakan dengan dua siklus ini, memenuhi tahapan berikut.

\section{Siklus 1}

a. Perencanaan

Berdasarkan masalah yang diidentifikasi pada observasi awal, telah direncanakan pembelajaran konsep Fluida Statik melalui penerapan media pembelajaran berbasis PHet untuk lebih memudahkan peserta didik memahami materi pembelajaran.

b. Pelaksanaan tindakan siklus I

Telah dilaksanakan pembelajaran menggunakan media PHET sesuai dengan kegiatan belajar mengajar yang dituangkan dalam RPP yaitu:

a) Aktivitas kegiatan pendahuluan

Dimulai mempersiapkan peserta didik mengikuti pembelajaran menggunakan medi PHET, memberi motivasi dan apersepsi terkait materi fluida statik, menjelaskan tujuan dan kompetensi dasar yang ingin dicapai pada pelaksanaan siklus pertama, menyampaikan caara penggunaan media PHET dalam pembelajaran.

b) Kegiatan Inti

Memberikan materi pembelajaran fluida statik melalui media pembelajaran PHET. Pembelajaran dilaksanakan dengan membagi peserta didik dalam kelompok kecil (4-5 orang), dan peserta didik difasilitasi guru menggunakan media PHET yang terkait materi fluida statik serta mendiskusikan materi yang diberikan. Dalam proses pembelajaran dilakukan obsertvasi dengan bantuan guru mata pelajaran fisika lainnya, untuk memberikan penilaian terhadap aktivitas pembelajaran.

c) Kegiatan penutup

Peserta didik dengan bimbingan guru menyimpulkan pembelajaran secara bersama, melakukan refleksi, melakukan kegiatan umpan balik dan tindak lanjut terkait dengan materi fluida statik.

c. Hasil Observasi Siklus I

Hasil dari pembelajaran menunjukkan adanya keterlibatan peserta didik yang cukup 
aktif dalam pembelajaran menggunakan media pembelajaran PHET. Hasil observasi aktivitas peserta didik pada siklus 1 didapatkan seperti Tabel 1.

Berdasarkan hasil pengamatan pada kegiatan pembelajaran melalui observasi didapatkan gambaran aktivitas peserta didik. Pada siklus I peserta didik masih banyak mengalami kendala-kendala antara lain:

a) Peserta didik masih asing dengan pembelajaran berbasis teknologi PHET yang diterapkan di kelas.

b) Peserta didik masih mengalami kesulitan memahami tugas yang diberikan.

c) Sebahagian masih kurang tertarik terhadap pelajaran Fisika, meskipun sudah menggunakan PHET.

Berdasarkan hasil observasi pada siklus I, guru telah melakukan proses pembelajaran sesuai yang telah direncanakan, walaupun masih terdapat kekurangan. Hasil observasi guru tentang pelaksanaan tindakan memperoleh skor 37,20. Berdasarkan hasil observasi siklus 1 dapat diketahui belum maksimalnya peningkatan aktivitas peserta didik dalam KBM.

Hasil belajar peserta didik siklus I memperoleh nilai rata-rata 78 . Dengan ketuntasan belajar peserta didik secara klasikal $65 \%$.

\section{Siklus II}

\section{a. Perencanaan}

Guru merumuskan masalah berdasarkan hasil refleksi siklus I, kemudian merancang kembali pembelajaran pada siklus II. Untuk siklus II dilakukan revisi KBM agar peserta didik dapat berperan lebih aktif.

b. Pelaksanaan tindakan siklus I

a) Pendahuluan

Menyiapkan peserta didik mengikuti pembelajaran melalui media PHET, memberi motivasi terhadap peserta didik melalui beberapa pernyataan, memberikan apersepsi melalui beberapa pertanyaan terkait materi Fluida yang akan dipelajari berdasarkan kehidupan nyata, menjelaskan tujuan dan kompetensi dasar yang ingin dicapai.

b) Inti

Melaksanakan rancangan yang sesuai dengan materi pembelajaran dan media pembelajaran PHET. Membagi kelompok, dan memberikan penugasan kepada peserta didik, tanya jawab kepada peserta didik..

c) Penutup

Peserta didik difasilitasi pendidik menyimpulkan pembelajaran secara bersama, melakukan refleksi, memberikan tindak lanjut.

\section{c. Hasil Observasi}

Hasil observasi menunjukkan bahwa peserta didik lebih aktif dalam pembelajaran pada siklus II. Prosentase keaktifan peserta didik mencapai $76,74 \%$ aktivitas peserta didik dalam mengikuti kegiatan pembelajaran dengan media PHET dapat terlihat dari aktivitas masing-masing peserta didik dalam kelompok. Diskusi di dalam kelas sudah menunjukkan peningkatan dan jumlah peserta didik yang mengajukan pertanyaan, mengemukakan pendapatnya dan menjawab pertanyaan guru dengan berani tanpa harus ditunjuk oleh guru.

Hasil analisis data yang dilakukan melalui tes hasil belajar setiap siklusnya dapat diketahui dari Tabel 2.

Tabel 2. Hasil belajar setiap siklus

\begin{tabular}{lcccc}
\hline \multirow{2}{*}{ Interval Nilai } & \multicolumn{2}{c}{ Siklus 1 } & \multicolumn{2}{c}{ Siklus 2 } \\
\cline { 2 - 5 } & Jml & $\%$ & Jml & $\%$ \\
\hline $0-74,9$ & 15 & 41,7 & 0 & 0 \\
$75-100$ & 21 & 58,3 & 36 & 100 \\
\hline Jumlah & 36 & 100 & 36 & 100 \\
\hline Nilai rata-rata & 78 & & 85 & \\
\hline
\end{tabular}

Berdasarkan data Tabel 2 diperoleh hasil bahwa peserta didik mengalami peningkatan dari siklus I ke siklus II yaitu dari siklus I terdapat $58,3 \%$ yang memperoleh nilai besar dari 75 dengan nilai rata 78 dan pada siklus II diperoleh 100\% memperoleh nilai lebih besar dari 75 dengan nilai rata-rata 85 . Hal ini menunjukkan bahawa penggunaan media PHET dapat meningkatkan pembelajaran fisika pada materi fluida satik dapat meningkatkan hasil belajar peserta didik. Selanjutnya dari data hasil observasi yang didapatkan menunjukkan bahwa aktivitas peserta didik dalam proses pembelajaran juga mengalami peningkatan dari siklus I ke siklus II. 
Media pembelajaran yang digunakan dalam penelitian ini berupa media pembelajaran interaktif tutorial berisi kompetensi yang harus dicapai peserta didik, tujuan pembelajaran, materi pelajaran fluida statik, simulasi yang berupa video dan peragaan, latihan soal dan cerita singkat tentang tokoh fisika yang mempelopori konsep fluida statik. Video maupun simulasi yang disajikan dalam media ini merupakan video dan peragaan yang dapat memberikan informasi kepada peserta didik mengenai konsep-konsep fluida statik. Dalam media pembeljaran ini juga disajikan eksperimen sederhana tentang hakum Pascal dan gaya apung yang diharapkan dapat lebih meningkatkan pemahaman dan keaktifan belajar peserta didik.

Dalam penelitian ini masing-masing kelompok dari kelas eksperimen melakukan praktikum sederhana menggunakan media simulasi PHET. Materi diskusi tentang hukum hidrostatika, hukum Pascal dan hukum Archimedes. Di kelas, kegiatan pembelajaran diawali dengan kegiatan apersepsi, dilanjutkan dengan tanya-jawab mengenai konsep fluida statik, kemudian peserta didik dibagi menjadi beberapa kelompok untuk melakukan simulasi penerapan hukum-hukum pada fluida statik menggunakan media pembelajaran. Setelah itu peserta didik melakukan praktikum dan diskusi sesuai dengan petunjuk pada LKPD, kemudian peserta didik mempresentasikan hasil diskusi di depan kelas dan guru memperjelas menggunakan bahan ajar dengan media simulasi. Kegiatan pembelajaran diakhiri dengan menyimpulkan secara bersama-sama tentang materi yang telah dipelajari.

Hasil analisis data menunjukkan bahwa terjadi peningkatan hasil belajar dan keaktifan peserta didik melalui penggunaan media PHet. Peningkatan hasil belajar yang ditampilkan menunjukkan bahwa kelas tindakan mengalami peningkatan hasil belajar. Hal ini karena pada pembelajaran fisika menggunakan media simulasi, peserta didik tertarik dengan media yang digunakan sehingga peserta didik lebih termotivasi untuk menguasai materi dan lebih percaya diri dalam proses pembelajaran. Dengan demikian kemampuan kognitif peserta didik meningkat setelah mengikuti pembelajaran dengan persentase peningkatan sebesar 30\%.
Pembelajaran menggunakan media simulasi berbasis teknologi informasi dapat mengembangkan proses berpikir kritis dan kreatif peserta didik. Melalui media simulasi, peserta didik dilatih untuk menyelesaikan masalah berdasarkan apa yang sedang diamatinya. Video dan simulasi yang tersaji dalam media dapat memotivasi peserta didik untuk berperan aktif mencari tahu konsep materi melalui kegiatan mengamati. Keaktifan peserta didik dalam proses pembelajaran dengan kegiatan praktikum sederhana menggunakan media pembelajaran PHET (Physics Education Technology) menjadi lebih terarah, hal tersebut mengindikasikan bahwa peserta didik menjadi lebih percaya diri dalam proses belajar di kelas sehingga hasil belajar peserta didik juga meningkat seiring keaktifan belajar peserta didik. Selain membantu peserta didik memahami materi pelajaran, media simulasi ini juga dapat membantu peserta didik belajar secara mandiri karena media pembelajaran simulasi berbantukan komputer bersifat linear yakni media dapat dijalankan kapan saja dan dimana saja peserta didik hendak belajar. Jadi, penggunaan media simulasi sebagai salah satu bentuk media pembelajaran berbasis teknologi dan informasi sesuai dengan pola pikir dikembangkannya kurikulum 2013 yaitu pembelajaran berbasis alat multimedia, pembelajaran aktif dan kritis sesuai Permendikbud nomor 69 (Permendikbud, 2013). Penggunaan media simulasi yang digunakan dalam penelitian ini juga dapat memberikan informasi tambahan kepada peserta didik tentang sejarah tokoh yang berkiprah dalam bidang fisika.

Hasil analisis menunjukkan bahwa penggunaan media simulasi berbasis teknologi informasi dapat meningkatkan pemahaman konsep dan keaktifan belajar peserta didik lintas minat fisika.Ini berarti penggunaan media simulasi sebagai salah satu alternatif media pembelajaran fisika mempunyai peran yang cukup penting. Ketidakjelasan dan kerumitan materi yang disampaikan dapat terbantu melalui perantara media. Sebagaimana Muller (2008) menyatakan bahwa media pembelajaran berpengaruh dalam pembelajaran fisika, sehingga peserta didik menjadi lebih tertarik. Selain itu juga media pembelajaran dapat memotivasi peserta didik sehingga, peserta didik merasa lebih percaya diri untuk belajar baik secara kelompok 
ataupun mandiri, sebagaimana disebutkan dalam hasil penelitian Sahin (2006) bahwa peserta didik tidak hanya termotivasi oleh adanya simulasi tetapi peserta didik juga diajak untuk berinteraksi dengan simulasi computer tersebut seperti halnya ketika peserta didik melakukannya di dunia nyata sehingga aktivitas peserta didik lebih terarah. Hal ini tentunya membawa pengaruh psikologis terhadap peserta didik serta berdampak pada hasil belajar peserta didik.

Pembelajaran fisika berbantukan media simulasi memberikan pengaruh positif terhadap hasil belajar peserta didik. Selain itu, peningkatan hasil belajar peserta didik yang menggunakan media simulasi lebih baik dari peningkatan hasil belajar peserta didik yang tidak menggunakan media, ditunjukkan dengan hasil uji signifikansi yang menyatakan bahwa terdapat perbedaan peningkatan pemahaman konsep dan keaktifan belajar peserta didik yang signifikan dalam pengunaan media simulasi dengan hanya penggunaan bahan ajar buku dalam pembelajaran fisika pada peserta didik lintas minat fisika di SMA Negeri 4 Pekanbaru.

Secara umum penggunaan media simulasi berbasis teknologi dan informasi dalam pembelajaran fisika dapat meningkatkan hasil belajar peserta didik. Hal ini dapat diketahui dari hasil belajar peserta didik yang mengalami kenaikan setelah dilaksanakan pembelajaran pada siklus II. Namun. Selain itu, pada saat pelaksanaan penelitian terdapat kendala media simulasi tidak dapat dibuka pada laptop salah satu kelompok karena media simulasi ini membutuhkan aplikasi khusus agar bisa terbuka. Hal tersebut sedikit menghambat pada saat awal penelitian. Selain itu, terbatasnya jumlah observer untuk mengamati sejumlah peserta didik yang tidak sedikit untuk pengamatan keaktifan belajar peserta didik juga menjadi keterbatasan dalam penelitian ini. Hasil belajar akan lebih optimal jika antara guru, media pembelajaran dan peserta didik terjalin interaksi sehingga proses belajar juga menjadi optimal dan berdampak baik pada hasil belajar.

\section{Kesimpulan dan Saran}

Penggunaan media PHET yang berbasis teknologi informasi dalam pembelajaran fisika dapat meningkatkan keaktifan belajar peserta didik lintas minat fisika di SMA Negeri 4 Pekanbaru. Besarnya peningkatan keaktifan belajar peserta didik yang menggunakan media pembelajaran mencapai $75 \%$. Kedua persentase gain tersebut menunjukkan bahwa peningkatan keaktifan belajar peserta didik kelas eksperimen lebih tinggi dari peserta didik kelas. Dapat disimpulkan bahwa penggunaan media simulasi sebagai media pembelajaran dapat meningkatkan keaktifan belajar.

Dapat dilakukan penelitian lanjutan terkait peningkatan motivasi peserta didik dan penguatan karakter peserta didik di dalam memahami pola pembelajaran dalam kegiatan pembelajaran fisika di berbagai jenis materi pembelajaran.

\section{Daftar Pustaka}

Arikunto, S., 2006. Prosedur Penelitian. Rineka Cipta, Jakarta.

Gunawan \& Liliasari, 2012. Model Virtual Laboratory Fisika Modern untuk Meningkatkan Disposisi Berpikir Kritis Calon Guru. Cakrawala Pendidikan. 31(2): 185-199.

Maulana, Andi I. \& Salmiah S., 2018. Penerapan Perangkat Pembelajaran Berbasis Laboratorium Virtual Pada Pencapaian Hasil Belajar Fisika Peserta Didik Kelas XI MIA 5 SMAN 15 Makassar. Universitas Negeri Makassar. Jurnal Sains dan Pendidikan Fisika, V 14, Nomor 1.

Kozma, R. B., 1991. Learning with Media. Review of Research. 61(2):179-212.

Muller, A. D., 2008. Designing Effective Multimedia for Physics Education. Thesis. University of Sydney.

Sinulingga, P., Hartanto, TJ. \& Santoso B., 2016. Implementasi Pembelajaran Fisika Berbantuan Media Simulasi PhET untuk Meningkatkan Hasil Belajar Siswa Pada Materi Listrik Dinamis. Jurnal Penelitian \& Pengembangan Pendidikan Fisika 2 (1), 57-64.

Snyder, G. L., Snyder, J. M., 2008. Teaching Critical Thingking and Problem Solving. The Delta Pi Epsilon Journal. V (2): 9099.

Zainudin. 2017. Pengembangan E-Learning Fisika Menggunakan Phet (Physics 
Educational Technology) Pada Materi Pokok Dinamika Gerak Lurus Berbasis Keterampilan Berfikir Kritis. Madura: STKIP PGRI Bangkalan. Jurnal Pena Sains Vol. 4, No. 1.

Usiana, W., \& Budiningarti, H., 2016. Penerapan Media Simulasi PhET dalam pembelajaran fisika kurikulum 2013 pada materi fluida dinamis untuk meningkatkan hasil belajar siswa kelas XI SMA Khadijah surabaya. Jurnal Inovasi Pendidikan Fisika (JIPF), vol. 5(03), 49-58.
Sahin, I., 2006. The Turkish Online. Journal of Educational Technology (TOJET), 5 (2), 14-23.

Sudjana, Nana., 2009. Penilaian Hasil Proses Belajar Mengajar. PT. Remaja Rosdakarya, Bandung. 